\title{
Produksi $\beta$-Glukosidase Aspergillus niger Bio 2173 dengan Fermentasi Padat menggunakan Substrat Dedak
}

\author{
Sri Sugiwati a,b, Maggy Thenawidjaja Suhartono a *, Muhammad Hanafi ${ }^{\text {b }}$, Hanifah Nuryani Lioe a \\ ${ }^{a}$ Departemen Ilmu dan Teknologi Pangan, Fakultas Teknologi Pertanian, Institut Pertanian Bogor, Bogor, \\ Indonesia \\ ${ }^{\mathrm{b}}$ Pusat Penelitian Kimia, Lembaga Ilmu Pengetahuan Indonesia (LIPI) Kawasan Puspiptek Serpong, Tangerang, \\ Indonesia
}

Diterima : 07 Maret 2018, Revisi akhir : 03 Mei 2018, Disetujui terbit : 07 Mei 2018

\section{Production of $\beta$-Glucosidase Aspergillus niger Bio 2173 on Solid State Fermentation using Rice Bran as Substrate}

\begin{abstract}
$\beta$-Glucosidase (EC 3.2.1.21) is a part of the cellulase enzyme complex which acts synergistically with exoglucanase and endoglucanase to hydrolize cellulose into glucose. The purpose of this study was to obtain the maximum fermentation conditions for production of $\beta$-glucosidase Aspergillus niger BIO 2173 with solid state fermentation using rice bran as fermentation substrate. The factors that affect the production of $\beta$-glucosidase which consist of initial $p H$ of the fermentation medium, incubation period, ratio of water content to fermentation substrate, incubation temperature and addition of the Mandel's mineral salts solution were examined in the study. The results showed that maximum fermentation conditions for $\beta$-glucosidase production were at initial of fermentation $p H$ of 2,0, incubation period of 7 days, ratio of water content to substrate of 1:1, and incubation temperature of $32^{\circ} \mathrm{C}$. Addition of Mandel's mineral salts solution to the fermentation substrate at maximum fermentation conditions increased the activity and spesific activity of $\beta$-glucosidase crude extract up to 5,24 $\pm 0,57 \mathrm{U} / \mathrm{mL}$ and $2,46 \pm 0,04 \mathrm{U} / \mathrm{mg}$ respectively.
\end{abstract}

Keywords: $\beta$-glucosidase, Aspergillus niger, rice bran, solid state fermentation, crude extract

\begin{abstract}
Abstrak
$\beta$-Glukosidase (EC 3.2.1.21) merupakan bagian dari enzim multi kompleks selulase, yang bekerja secara sinergis dengan eksoglukanase dan endoglukanase menghidrolisis selulosa menjadi glukosa. Tujuan dari penelitian ini adalah mendapatkan kondisi fermentasi maksimum untuk produksi $\beta$-glukosidase Aspergillus niger BIO 2173 dengan fermentasi media padat menggunakan substrat dedak. Pengujian dilakukan terhadap faktor-faktor yang mempengaruhi produksi $\beta$-glukosidase, yaitu $\mathrm{pH}$ awal medium fermentasi, waktu inkubasi, perbandingan kandungan air terhadap substrat medium fermentasi, suhu inkubasi dan penambahan larutan garam mineral Mandels. Hasil penelitian menunjukkan bahwa kondisi fermentasi maksimum untuk produksi $\beta$-glukosidase adalah pada $\mathrm{pH}$ awal medium fermentasi 2,0, waktu inkubasi 7 hari, perbandingan kandungan air terhadap substrat medium fermentasi 1:1, dan suhu inkubasi $32^{\circ} \mathrm{C}$. Penambahan larutan garam mineral Mandels ke dalam substrat fermentasi pada kondisi fermentasi maksimum menyebabkan peningkatan aktivitas dan aktivitas spesifik ekstrak kasar $\beta$-glukosidase masing-masing sebesar 5,24 $\pm 0,57 \mathrm{U} / \mathrm{mL}$ dan 2,46 $\pm 0,04 \mathrm{U} / \mathrm{mg}$ protein.
\end{abstract}

Kata kunci: $\beta$-glukosidase, Aspergillus niger, dedak padi, fermentasi padat, ekstrak kasar 


\section{Pendahuluan}

$\beta$-Glukosidase ( $\beta$-D-glukosida glukohidrolase, EC 3.2.1.21) merupakan bagian dari enzim multikompleks selulase. $\beta$-Glukosidase memiliki banyak manfaat potensial untuk digunakan pada berbagai proses bioteknologi seperti pelepasan rasa (flavor), aroma, aglikon isoflavon dan untuk sintesis oligosakarida dan alkil glikosida. Pada produksi bioetanol dari biomassa lignoselulosa, $\beta$-glukosidase berperan dalam menghidrolisis selobiosa yang merupakan senyawa intermediet dari hidrolisis selulosa menjadi monomer glukosa (Krisch et al., 2010, Singhania et al., 2013) sedangkan pada industri pulp dan kertas, $\beta$-glukosidase bersama-sama dengan selulase dan hemiselulase digunakan untuk menghilangkan warna tinta pada proses daur ulang limbah kertas (Ahmed et al., 2017).

Hidrolisis selulosa menjadi glukosa melibatkan enzim multi kompleks selulase yang terdiri dari tiga macam enzim, yaitu endoglukanase, eksoglukanase dan $\beta$-glukosidase. Ketiga macam enzim tersebut bekerja secara sinergis untuk hidrolisis lengkap selulosa menjadi glukosa melalui beberapa tahapan hidrolisis. Pada tahap pertama, serat selulosa dihidrolisis oleh endoglukanase melepaskan fragmen selulosa kecil dengan bagian ujung/terminal bebas dalam bentuk pereduksi dan non pereduksi, yang kemudian dihidrolisis lebih lanjut oleh eksoglukanase melepaskan oligosakarida berukuran kecil dan selobiosa. Pada tahap akhir, $\beta$-glukosidase melengkapi hidrolisis selulosa dengan menghidrolisis selobiosa (produk intermediet hidrolisis selulosa) menjadi monomer glukosa (Krisch et al., 2010, Singhania et al., 2013).

$\beta$-Glukosidase terdapat pada bakteri, kapang, tanaman dan hewan. Kapang merupakan sumber $\beta$-glukosidase yang telah banyak dilaporkan. Isolasi $\beta$-glukosidase dari kapang dilakukan baik dengan menggunakan metode fermentasi media padat maupun fermentasi media cair (Singhania et al., 2013). Berbagai jenis kapang telah dijadikan sebagai sumber $\beta$-glukosidase seperti Aspergillus niger (Raza et al., 2011; Zahoor et al., 2011; Qian et al., 2012; Junior et al., 2014; Ahmed et al., 2015 Julia et al., 2016), Aspergillus terreus (Elshafei et al., 2011), Aspergillus fumigatus (Liu et al., 2012), Fusarium proliferatum (Gao et al., 2012), Penicillium pinophilum (Joo et al., 2010), Penicillium italicum (Park et al., 2012), Trichoderma viride (Irshad et al., 2013), dan Trichoderma reesei (Zheng et al., 2017).
Aspergillus niger merupakan mikroorganisme yang paling banyak digunakan dalam industri fermentasi seperti produksi asam organik (Yang et al., 2017), enzim hidrolitik lipase (Salihu et al., 2016) dan amilase (Carrillo-Sancen et al., 2016). Aspergillus niger juga merupakan sumber $\beta$-glukosidase yang potensial. Hal ini disebabkan karena kemudahannya untuk dikultivasi pada media produk agro dengan fermentasi media padat maupun fermentasi media cair. Selain itu, Aspergillus niger telah dinyatakan oleh Food and Drug Administration (FDA) Amerika Serikat sebagai GRAS (generally regarded as safe) (Silva et al., 2011; Qian et al., 2012). Beberapa penelitian produksi $\beta$-glukosidase yang menggunakan Aspergillus niger sebagai sumber enzim, diantaranya adalah Junior et al. (2014) yang melakukan isolasi $\beta$-glukosidase dari Aspergillus niger dengan fermentasi media padat menggunakan substrat kulit ari gandum (wheat bran) dan purifikasi parsial menggunakan MANAE-agarose menghasilkan larutan enzim dengan aktivitas spesifik 17,1 IU/mg dan $\mathrm{Hu}$ et al. (2011) yang melakukan isolasi $\beta$-glukosidase dari Aspergillus niger dengan medium minimal Aspergillus dan 1\% wheat bran menghasilkan ekstrak kasar enzim dengan aktivitas $3,3 \pm 0,1 \mathrm{nmol} / \mathrm{min} / \mathrm{mL}$ dan kultur campuran Aspergillus niger dan A. oryzae dengan aktivitas $4,9 \pm 0,1 \mathrm{nmol} / \mathrm{min} / \mathrm{mL}$.

Penelitian ini bertujuan untuk memproduksi $\beta$-glukosidase Aspergillus niger BIO 2173 dan mempelajari faktor-faktor yang mempengaruhi produksinya, yaitu $\mathrm{pH}$ awal medium fermentasi, waktu inkubasi fermentasi, perbandingan kandungan air terhadap substrat media fermentasi, suhu inkubasi fermentasi dan penambahan larutan garam mineral Mandels (Mandels dan Reese, 1957). Proses fermentasi dilakukan dengan teknik fermentasi media padat menggunakan substrat dedak. Hasil fermentasi diekstrak dan terhadap ekstrak kasar dilakukan uji aktivitas dengan menggunakan substrat $p$-nitrophenyl$\beta$-D-glucopyranoside ( $p \mathrm{NPG})$, uji protein dan ditentukan aktivitas spesifiknya.

\section{Bahan dan Metode}

\section{Bahan dan Alat}

Bahan yang digunakan dalam penelitian ini adalah $\mathrm{Na}_{2} \mathrm{CO}_{3}, \mathrm{CuSO}_{4} .5 \mathrm{H}_{2} \mathrm{O}, \mathrm{KNa}$-Tartrat, pereaksi Folin-Ciocalteu, Bovin Serum Albumin 
(BSA), $p$-nitrophenyl- $\beta$-D-glucopyranoside (Sigma Aldrich), $\mathrm{CH}_{3} \mathrm{COONa}$, asam asetat $96 \%$, Potato Dextrose Agar (PDA), larutan garam mineral Mandels : urea $0,3 \mathrm{~g} / \mathrm{L},\left(\mathrm{NH}_{4}\right)_{2} \mathrm{SO}_{4} 1,4 \mathrm{~g} / \mathrm{L}$, $\mathrm{KH}_{2} \mathrm{PO}_{4} \quad 2,0 \quad \mathrm{~g} / \mathrm{L}, \quad \mathrm{CaCl}_{2} \cdot 2 \mathrm{H}_{2} \mathrm{O} \quad 0,4 \quad \mathrm{~g} / \mathrm{L}$, $\mathrm{MgSO}_{4} \cdot 7 \mathrm{H}_{2} \mathrm{O} 0,3 \mathrm{~g} / \mathrm{L}$, pepton $1,0 \mathrm{~g} / \mathrm{L}$, Tween 80 $0,2 \mathrm{~g} / \mathrm{L}, \mathrm{FeSO}_{4} \cdot 7 \mathrm{H}_{2} \mathrm{O} 0,005 \mathrm{~g} / \mathrm{L}, \mathrm{MnSO}_{4} \cdot 7 \mathrm{H}_{2} \mathrm{O}$ $0,0016 \mathrm{~g} / \mathrm{L}, \quad \mathrm{ZnSO}_{4} \cdot 7 \mathrm{H}_{2} \mathrm{O} \quad 0,0016 \mathrm{~g} / \mathrm{L}$, dan $\mathrm{CoCl}_{2} \cdot 6 \mathrm{H}_{2} \mathrm{O} 0,02 \mathrm{~g} / \mathrm{L}$. Peralatan yang digunakan antara lain Spektrofotometer UV/Vis (Optizen 2120 uv, Mecacys Co., Ltd, Korea Selatan), sentrifuge refrigerator (Combi 514R, Hanil Scientific InC, Korea Selatan), pH meter (Seven Easy S20, Mettler Toledo, USA).

\section{Substrat Media Fermentasi}

Substrat yang digunakan sebagai media fermentasi pada penelitian ini adalah dedak padi yang diperoleh dari daerah Karawang, Jawa Barat.

\section{Mikroorganisme}

Mikroorganisme yang digunakan pada penelitian ini adalah isolat kapang Aspergillus niger BIO 2173 yang diisolasi dari gabah, diperoleh dari Laboratorium Fitopatologi, Southeast Asian Regional Centre for Tropical Biology (SEAMEO BIOTROP), Bogor.

\section{Metode}

\section{Penyegaran (Regenerasi) Aspergillus niger}

Penyegaran kapang Aspergillus niger dilakukan dengan menumbuhkan kapang yang berasal dari media agar miring Potato Dextrose Agar (PDA). Kapang Aspergillus niger diinokulasikan pada tabung reaksi berisi media agar miring PDA steril secara aseptis, selanjutnya diinkubasi pada suhu $28^{\circ} \mathrm{C}$ selama 5 hari (Ahmed et al., 2015).

\section{Produksi dan Ekstraksi $\beta$-Glukosidase}

Produksi $\beta$-glukosidase dilakukan dengan fermentasi media padat menggunakan substrat dedak padi berukuran 40 mesh. Ke dalam $10 \mathrm{~g}$ substrat ditambahkan akuades sebanyak $10 \mathrm{~mL}$. Kemudian dimasukkan kedalam erlenmeyer $100 \mathrm{~mL}$ dan disterilisasi dalam autoklaf pada $121^{\circ} \mathrm{C}$ selama 30 menit. Setelah dingin, ke dalam masing-masing erlenmeyer tersebut diinokulasi dengan Aspergillus niger hasil peremajaan yang berusia 5 hari sebanyak $1 \mathrm{~mL}$ suspensi spora $\left(10^{7}\right.$ spora). Selanjutnya, diinkubasi selama 7 hari pada suhu $28^{\circ} \mathrm{C}$ dengan $\mathrm{pH}$ awal media fermentasi 6,0. Jumlah spora kapang Aspergillus niger yang digunakan ditentukan dengan hemocytometer (Junior et al., 2014; Razaet al., 2011).

Hasil fermentasi diekstrak dengan larutan penyangga asetat $0,05 \mathrm{M}(\mathrm{pH} 5,0)$ sebanyak $50 \mathrm{~mL}$ kemudian digoyang dengan shaker dengan kecepatan $120 \mathrm{rpm}$ selama 1 jam. Selanjutnya, larutan tersebut disaring menggunakan kain kasa untuk menghilangkan miselia. Filtrat yang dihasilkan kemudian disentrifugasi pada suhu $4^{\circ} \mathrm{C}$ dengan kecepatan $6000 \mathrm{rpm}$ selama 10 menit (Junior et al., 2014; Raza et al., 2011). Supernatant yang didapat merupakan ekstrak kasar enzim untuk selanjutnya ditentukan aktivitas dan aktivitas spesifiknya.

\section{Penentuan Kondisi Maksimum Produksi $\beta$-Glukosidase}

Penentuan kondisi fermentasi maksimum untuk produksi $\beta$-glukosidase dilakukan dengan pengujian terhadap faktor-faktor yang mempengaruhi produksi enzim, yaitu $\mathrm{pH}$ awal medium fermentasi, waktu inkubasi fermentasi, perbandingan kandungan air terhadap substrat medium fermentasi, suhu inkubasi fermentasi dan penambahan larutan garam mineral Mandels pada medium fermentasi. Berikut ini adalah prosedur pengujian terhadap faktor-faktor yang mempengaruhi produksi $\beta$-glukosidase:

a. Pengujian terhadap pengaruh $\mathrm{pH}$ dilakukan dengan mengatur $\mathrm{pH}$ awal medium fermentasi pada kisaran $\mathrm{pH}$ dari 2,$0 ; 3,0 ; 4,0 ; 4,5 ; 5,0$; 5,$5 ; 6,0$; dan 7,0 menggunakan $1 \mathrm{mmol} / \mathrm{L}$ $\mathrm{HCl}$ atau $1 \mathrm{mmol} / \mathrm{L} \mathrm{NaOH}$. Nilai kisaran pH 2,0 - 7,0 mengacu pada penelitian Qian et al. (2012). Fermentasi dilakukan dengan menambahkan $10 \mathrm{~mL}$ pelarut $(\mathrm{pH} \mathrm{2,0-7,0)}$ ke dalam $10 \mathrm{~g}$ substrat, kemudian diinkubasi pada suhu $28^{\circ} \mathrm{C}$ selama 7 hari.

b. Pengujian terhadap pengaruh waktu inkubasi fermentasi dilakukan dengan menambahkan $10 \mathrm{~mL}$ akuades ke dalam $10 \mathrm{~g}$ substrat, kemudian diinkubasi pada suhu inkubasi $28^{\circ} \mathrm{C}$ dengan variasi waktu inkubasi selama 1, 2, 3, $4,5,6,7,8$, dan 9 hari, dan $\mathrm{pH}$ awal medium fermentasi 6,0. Penambahan volume akuades sebanyak $10 \mathrm{~mL}$ ke dalam $10 \mathrm{~g}$ substrat, 
mengacu pada penelitian Raza et al. (2011). Nilai $\mathrm{pH}$ 6,0 adalah $\mathrm{pH}$ awal media yang terukur tanpa penambahan $\mathrm{HCl}$ atau $\mathrm{NaOH}$.

c. Pengujian terhadap pengaruh variasi perbandingan kandungan air terhadap substrat media fermentasi, dilakukan dengan menambahkan masing-masing sebanyak 5, 10, 15, 20 dan $25 \mathrm{~mL}$ akuades ke dalam $10 \mathrm{~g}$ substrat dalam erlenmeyer $100 \mathrm{~mL}$. Inkubasi fermentasi dilakukan pada suhu $28^{\circ} \mathrm{C}$ selama 7 hari dan $\mathrm{pH}$ awal media fermentasi 6,0.

d. Pengujian terhadap pengaruh suhu inkubasi fermentasi dilakukan pada variasi suhu $28^{\circ} \mathrm{C}$, $32^{\circ} \mathrm{C}$, dan $36^{\circ} \mathrm{C}$ dengan waktu inkubasi selama 7 hari dan $\mathrm{pH}$ awal media fermentasi 6,0.

e. Pengujian terhadap pengaruh penambahan larutan garam mineral Mandels dilakukan dengan fermentasi pada kondisi maksimum dengan menambahkan larutan garam mineral Mandels sebanyak $10 \mathrm{~mL}$ ke dalam $10 \mathrm{~g}$ substrat. Sebagai pembanding dilakukan juga fermentasi dengan substrat sebanyak $10 \mathrm{~g}$ dan akuades $10 \mathrm{~mL}$ (Raza et al., 2011).

\section{Penentuan Aktivitas Ekstrak Kasar $\beta$-Glukosidase}

Aktivitas ekstrak kasar $\beta$-glukosidase ditentukan dengan menggunakan $p$-nitrophenyl$\beta$-D-glucopyranoside ( $p$ NPG) sebagai substrat. Sebanyak 1,0 mL larutan $2 \mathrm{mM}$ substrat $p$-nitrophenyl- $\beta$-D-glucopyranoside dalam $0,05 \mathrm{M}$ larutan penyangga natrium asetat $(\mathrm{pH} 5,0)$ diinkubasi pada suhu $40^{\circ} \mathrm{C}$ selama 5 menit. Selanjutnya, ditambahkan $0,1 \mathrm{~mL}$ larutan ekstrak kasar. Setelah 10 menit, reaksi dihentikan dengan menambahkan 2,0 mL larutan $1 \mathrm{M} \mathrm{Na}_{2} \mathrm{CO}_{3}$. Pengukuran absorbansi dilakukan pada panjang

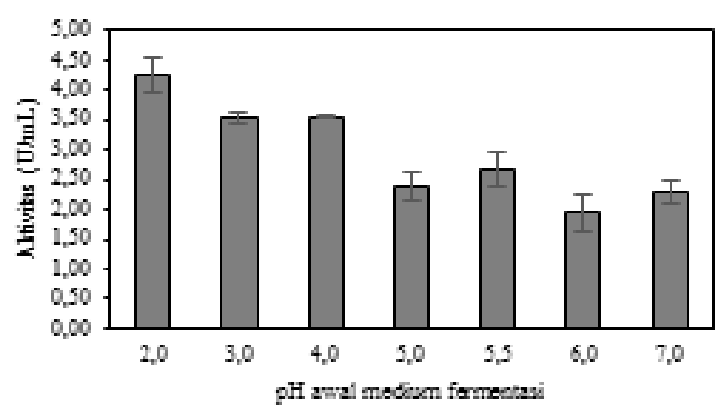

Gambar 1. Efek pH Awal Medium Fermentasi terhadap Aktivitas Ekstrak Kasar $\beta$-glukosidase Aspergillus niger BIO 2173 gelombang $405 \mathrm{~nm}$. Satu unit (U) $\beta$-glukosidase dinyatakan sebagai jumlah ekstrak kasar yang mengkatalisa hidrolisis $p$-NPG untuk melepaskan $1 \mu$ mol $p$-nitrophenol per menit pada kondisi percobaan (Herr et al., 1978).

\section{Penentuan Kadar Protein dalam Ekstrak Kasar $\beta$-Glukosidase}

Penentuan kadar protein dilakukan dengan metode Lowry menggunakan Bovine Serum Albumin (BSA) sebagai standar. Selanjutnya, kadar protein digunakan untuk menghitung aktivitas spesifik yang merupakan rasio dari aktivitas enzim terhadap kadar protein (Lowry et al., 1951).

\section{Hasil dan Pembahasan}

\section{Efek pH Awal Medium Fermentasi terhadap Produksi $\beta$-Glukosidase}

Nilai $\mathrm{pH}$ medium fermentasi dapat mempengaruhi pertumbuhan mikroorganisme sehingga berpengaruh terhadap produksi metabolit. Untuk mengetahui pengaruh $\mathrm{pH}$ terhadap produksi $\beta$-glukosidase dilakukan fermentasi padat Aspergillus niger BIO 2173 menggunakan substrat dedak dengan rentang $\mathrm{pH}$ awal medium fermentasi, yaitu $\mathrm{pH} 2,0-7,0$. Nilai $\mathrm{pH}$ yang diatur adalah $\mathrm{pH}$ kondisi awal fermentasi, sedangkan terhadap $\mathrm{pH}$ selama proses berlangsung tidak dilakukan pengendalian. Pada Gambar 1 dan Tabel 1 dapat dilihat pengaruh $\mathrm{pH}$ awal medium fermentasi terhadap aktivitas,

Tabel 1. Aktivitas Spesifik dan Kadar Protein Ekstrak Kasar $\beta$-glukosidase Aspergillus niger BIO 2173 pada Berbagai $\mathrm{pH}$ Awal Medium Fermentasi

\begin{tabular}{lcc}
\hline $\begin{array}{l}\mathrm{pH} \text { awal } \\
\text { medium } \\
\text { fermentasi }\end{array}$ & $\begin{array}{c}\text { Kadar protein } \\
(\mathrm{mg} / \mathrm{mL})\end{array}$ & $\begin{array}{c}\text { Aktivitas spesifik } \\
\text { (U/mg protein) }\end{array}$ \\
\hline 2,0 & $2,03 \pm 0,08$ & $2,10 \pm 0,07$ \\
3,0 & $2,01 \pm 0,06$ & $1,76 \pm 0,01$ \\
4,0 & $2,25 \pm 0,05$ & $1,58 \pm 0,03$ \\
5,0 & $2,39 \pm 0,06$ & $1,01 \pm 0,13$ \\
5,5 & $1,93 \pm 0,13$ & $1,38 \pm 0,06$ \\
6,0 & $2,06 \pm 0,24$ & $0,94 \pm 0,05$ \\
7,0 & $1,98 \pm 0,10$ & $1,16 \pm 0,04$ \\
\hline
\end{tabular}


aktivitas spesifik dan kadar protein ekstrak kasar $\beta$-glukosidase Aspergillus niger BIO 2173.

Produksi $\beta$-glukosidase pada rentang $\mathrm{pH}$ awal medium fermentasi 2,0-7,0 menghasilkan ekstrak kasar $\beta$-glukosidase dengan nilai aktivitas 1,94 - 4,25 U/mL dan nilai aktivitas spesifik $0,94-2,10 \mathrm{U} / \mathrm{mg}$ protein. Produksi $\beta$-glukosidase mencapai maksimum pada $\mathrm{pH}$ awal medium fermentasi 2,0. Selanjutnya, peningkatan $\mathrm{pH}$ awal medium fermentasi menyebabkan penurunan aktivitas dan aktivitas spesifik ekstrak kasar $\beta$-glukosidase. Penurunan produksi $\beta$-glukosidase dengan meningkatnya $\mathrm{pH}$ awal medium fermentasi disebabkan karena sebagian besar kapang berfilamen tumbuh lebih baik pada $\mathrm{pH}$ asam dan karenanya menghasilkan produksi enzim yang lebih tinggi. Kondisi $\mathrm{pH}$ basa memiliki efek penghambatan terhadap pertumbuhan kapang dan produksi enzim. Selain itu, kultivasi kapang pada nilai $\mathrm{pH}$ yang kurang menguntungkan juga dapat menurunkan produksi enzim dengan cara mengurangi aksesibilitas substrat (Bakri et al., 2008).

Nilai $\mathrm{pH}$ maksimum untuk produksi $\beta$-glukosidase yang diperoleh pada penelitian ini berbeda dengan hasil penelitian yang dilakukan oleh Zahoor et al. (2011) yang melakukan produksi $\beta$-glukosidase dari Aspergillus niger NRRL 599 dengan teknik fermentasi media cair menggunakan substrat kulit ari biji gandum mendapatkan $\mathrm{pH}$ maksimumpada 5,5. Raza et al. (2011) yang mempelajari efek $\mathrm{pH}$ awal medium fermentasi terhadap produksi $\beta$-glukosidase dari campuran kultur Aspergillus niger dan A. oryzae menggunakan substrat kulit ari biji gandum juga mendapatkan $\mathrm{pH}$ maksimum pada 5,5. Qian et al. (2012) mempelajari efek $\mathrm{pH}$ awal medium fermentasi terhadap produksi $\beta$-glukosidase dari Aspergillus niger AS 3.4309 menggunakan substrat kulit ari biji gandum mendapatkan $\mathrm{pH}$ maksimum pada 6,0 .

\section{Efek Waktu Inkubasi Fermentasi terhadap Produksi $\beta$-Glukosidase}

Produksi $\beta$-glukosidase dipengaruhi oleh waktu inkubasi fermentasi. Penentuan waktu inkubasi fermentasi maksimum pada produksi ekstrak kasar $\beta$-glukosidase dari Aspergillus niger BIO 2173 dilakukan dengan variasi waktu inkubasi 1 - 9 hari. Produksi enzim akan meningkat dengan bertambahnya periode waktu inkubasi dan menurun setelah mencapai waktu inkubasi maksimum. Pada Gambar 2 dan Tabel 2 dapat dilihat pengaruh waktu inkubasi fermentasi Aspergillus niger BIO 2173 terhadap aktivitas, aktivitas spesifik dan kadar protein ekstrak kasar $\beta$-glukosidase.

Produksi $\beta$-glukosidase pada waktu inkubasi fermentasi $1-9$ hari, menghasilkan ekstrak kasar $\beta$-glukosidase dengan nilai aktivitas $0,03-3,70 \quad \mathrm{U} / \mathrm{mL}$ dan nilai aktivitas spesifik $0,01-1,29 \mathrm{U} / \mathrm{mg}$ protein. Pada fermentasi hari ke-1 produksi $\beta$-glukosidase sangat rendah dan mulai meningkat secara perlahan pada fermentasi hari ke-2 sampai ke4. Produksi $\beta$-glukosidase meningkat dengan cepat pada fermentasi hari ke-5 sampai ke-6 dan mencapaimaksimum pada fermentasi hari ke-7. Penambahan waktu inkubasi fermentasi menjadi 9 hari menyebabkan penurunan aktivitas dan aktivitas spesifiknya. Penurunan produksi $\beta$-glukosidase dengan penambahan waktu fermentasi setelah mencapai produksi maksimum kemungkinan disebabkan oleh berkurangnya makronutrien dan mikronutrien di dalam media fermentasi, sejalan dengan berlangsungnya proses fermentasi, sehingga menekan fisiologi jamur yang menyebabkan inaktivasi dari mesinmesin (organel sel) penghasil enzim (Ikram-ulHaq et al., 2006).

Hasil penelitian Raza et al. (2011) yang melakukan produksi $\beta$-glukosidase dari campuran kultur Aspergillus niger dan A oryzae menggunakan substrat kulit ari biji gandum dengan variasi waktu inkubasi $1-5$ hari mendapatkan waktu inkubasi maksimum pada hari ke-3. Sementara itu, Gautam et al. (2011) yang melakukan produksi $\beta$-glukosidase dari

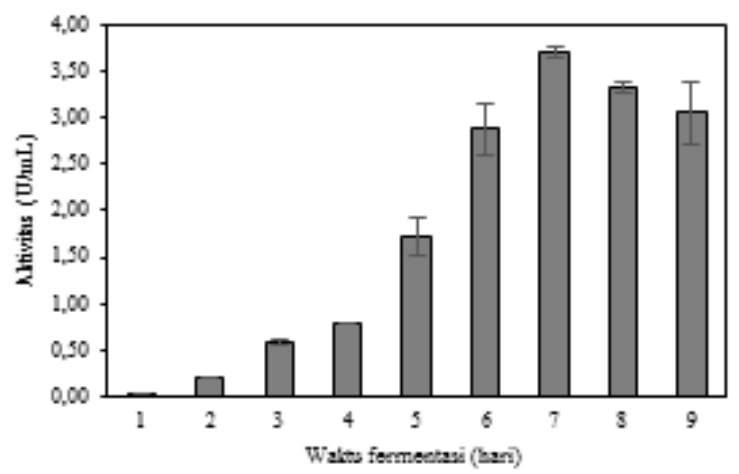

Gambar 2. Efek Waktu Fermentasi terhadap Aktivitas Ekstrak Kasar b-glukosidase Aspergillus Niger BIO 2173 
Tabel 2. Aktivitas Spesifik dan Kadar Protein Ekstrak Kasar b-glukosidase dari Aspergillus niger BIO 2173 pada berbagai Waktu Fermentasi

\begin{tabular}{lcc}
\hline $\begin{array}{l}\text { Waktu } \\
\text { fermentasi } \\
\text { (hari) }\end{array}$ & $\begin{array}{c}\text { Kadar Protein } \\
(\mathrm{mg} / \mathrm{mL})\end{array}$ & $\begin{array}{c}\text { Aktivitas } \\
\text { spesifik } \\
(\mathrm{U} / \mathrm{mg} \text { protein })\end{array}$ \\
\hline 1 & $4,66 \pm 0,01$ & $0,01 \pm 0,00$ \\
2 & $5,18 \pm 0,08$ & $0,04 \pm 0,00$ \\
3 & $4,48 \pm 0,33$ & $0,13 \pm 0,02$ \\
4 & $3,56 \pm 0,01$ & $0,22 \pm 0,00$ \\
5 & $3,42 \pm 0,00$ & $0,50 \pm 0,06$ \\
6 & $3,39 \pm 0,24$ & $0,86 \pm 0,14$ \\
7 & $2,88 \pm 0,18$ & $1,29 \pm 0,06$ \\
8 & $2,88 \pm 0,05$ & $1,15 \pm 0,04$ \\
9 & $2,61 \pm 0,51$ & $1,19 \pm 0,11$ \\
\hline
\end{tabular}

Aspergillus niger yang diinokulasi pada media basal dengan waktu inkubasi pada suhu $45^{\circ} \mathrm{C}$ selama 7 hari memperoleh aktivitas $\beta$-glukosidase maksimum $(1,61 \mathrm{U} / \mathrm{mL})$ pada fermentasi hari ke-3 -5 .

\section{Efek Kandungan Air pada Substrat Medium Fermentasi terhadap Produksi $\beta$-Glukosidase}

Efek dari variasi kandungan air dalam substrat medium fermentasi terhadap aktivitas, aktivitas spesifik dan kadar protein $\beta$-glukosidase Aspergillus niger BIO 2173 dapat dilihat pada Gambar 3 dan Tabel 3. Pada substrat dedak sebanyak 10 gram yang ditambahkan akuades masing-masing sebanyak 5-30 mL menghasilkan ekstrak kasar $\beta$-glukosidase dengan nilai aktivitas $0,25-6,32 \mathrm{U} / \mathrm{mL}$ dan nilai aktivitas spesifik $0,10-1,99 \mathrm{U} / \mathrm{mg}$ protein.

Produksi $\beta$-glukosidase mencapai maksimum pada kandungan air $10 \mathrm{~mL}$ dan substrat dedak 10 gram dengan rasio perbandingan volume air terhadap substrat sebesar 1:1. Selanjutnya, penambahan volume air sampai $30 \mathrm{~mL}$ menyebabkan penurunan produksi ekstrak kasar $\beta$-glukosidase. Terjadinya penurunan produksi $\beta$-glukosidase dengan bertambahnya volume air, kemungkinan disebabkan oleh ketidakcukupan asupan udara akibat tingginya volume air sehingga menyebabkan terhambatnya pertumbuhan mikroba dan produksi enzim (Raza et al., 2011).

Produksi $\beta$-glukosidase pada penambahan akuades sebanyak $5 \mathrm{~mL}$ lebih rendah

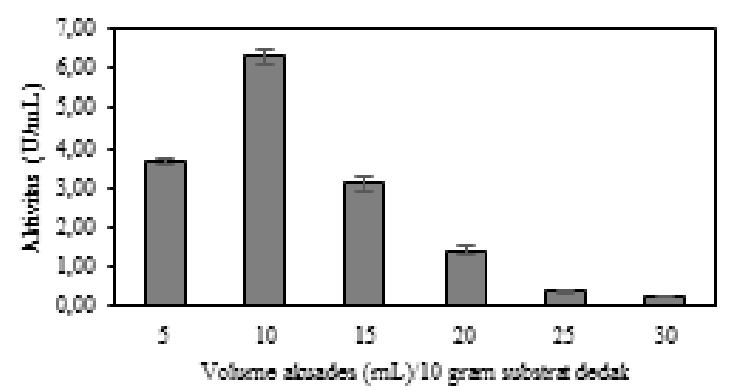

Gambar 3. Efek Perbedaan Kandungan Air yang Ditambahkan pada 10 gram Substrat Dedak terhadap Aktivitas Ekstrak Kasar $\beta$-glukosidase Aspergillus niger $\mathrm{BIO} 2173$

daripada $10 \mathrm{~mL}$. Hal ini disebabkan karena berkurangnya volume air pada media fermentasi padat menyebabkan berkurangnya kandungan air dalam media sehingga menurunkan kelarutan nutrisi substrat dan terjadinya pengembangan (swelling) meningkatkan kehilangan air akibat penguapan yang cepat selama fermentasi sehingga menghambat pertumbuhan mikroorganisme (Lonsane et al., 1985).

\section{Efek Suhu Inkubasi Fermentasi terhadap Produksi $\beta$-Glukosidase}

Faktor fermentasi lainnya yang mempengaruhi produksi $\beta$-glukosidase selain $\mathrm{pH}$, waktu inkubasi fermentasi, dan perbedaan rasio kandungan air terhadap substrat medium fermentasi, adalah suhu inkubasi fermentasi. Penentuan pengaruh suhu terhadap produksi $\beta$-glukosidase dilakukan inkubasi fermentasi pada tiga suhu yang berbeda, yaitu $28^{\circ} \mathrm{C}, 32^{\circ} \mathrm{C}$ dan $36^{\circ} \mathrm{C}$. Pada Gambar 4 dan Tabel 4 dapat dilihat pengaruh suhu inkubasi

Tabel 3. Aktivitas Spesifik dan Kadar Protein Ekstrak Kasar $\beta$-glukosidase Aspergillus niger BIO 2173 pada Berbagai Kandungan Air dalam 10 gram Substrat Dedak

\begin{tabular}{lcc}
\hline $\begin{array}{l}\text { Volume } \\
\text { akuades } \\
(\mathrm{mL})\end{array}$ & $\begin{array}{c}\text { Kadar Protein } \\
(\mathrm{mg} \mathrm{m} / \mathrm{L})\end{array}$ & $\begin{array}{c}\text { Aktivitas spesifik } \\
(\mathrm{U} \text { mg/protein })\end{array}$ \\
\hline 5 & $4,80 \pm 0,05$ & $0,77 \pm 0,01$ \\
10 & $3,18 \pm 0,08$ & $1,99 \pm 0,02$ \\
15 & $2,80 \pm 0,10$ & $1,11 \pm 0,02$ \\
20 & $1,98 \pm 0,03$ & $0,72 \pm 0,05$ \\
25 & $1,98 \pm 0,08$ & $0,19 \pm 0,02$ \\
30 & $2,47 \pm 0,14$ & $0,10 \pm 0,01$ \\
\hline
\end{tabular}




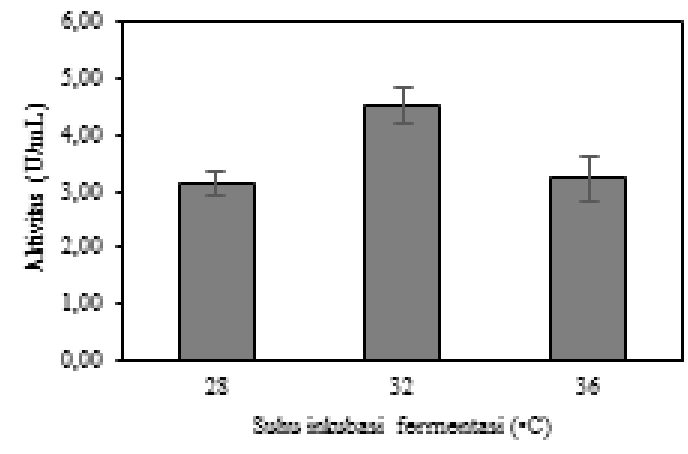

Gambar 4. Pengaruh Suhu Inkubasi Fermentasi terhadap Aktivitas Ekstrak Kasar $\beta$-glukosidase Aspergillus niger BIO 2173

terhadap aktivitas, aktivitas spesifik dan kadar protein ekstrak kasar $\beta$-glukosidase Aspergillus niger BIO 2137.

Produksi $\beta$-glukosidase paling tinggi dicapai pada suhu inkubasi fermentasi $32^{\circ} \mathrm{C}$. Penurunan suhu inkubasi menjadi $28^{\circ} \mathrm{C}$ dan peningkatan menjadi $36^{\circ} \mathrm{C}$ menyebabkan penurunan produksi ekstrak kasar $\beta$-glukosidase. Berkurangnya produksi pada suhu yang lebih rendah disebabkan oleh terhambatnya transport nutrisi ke dalam sel, sedangkan pada suhu tinggi terjadi peningkatan kebutuhan energi untuk pemeliharaan sel akibat dari inaktivasi protein dari jalur metabolik sehingga pembentukan produk menjadi berkurang (Rajoka et al., 2004).

Suhu inkubasi maksimum yang didapatkan pada penelitian ini tidak jauh berbeda dengan hasil penelitian Zahoor et al. (2011) yang melakukan produksi $\beta$-glukosidase dari Aspergillus niger NRRL 599 menggunakan substrat kulit ari biji gandum, yaitu pada suhu $30^{\circ} \mathrm{C}$, dan Qian et al. (2012) yang melakulan produksi $\beta$-glukosidase dari Aspergillus niger AS 3.4309 dengan substrat kulit ari biji gandum, mendapatkan suhu optimum pada $28^{\circ} \mathrm{C}$. Sedangkan Gautam et al. (2011) yang melakukan produksi $\beta$-glukosidase dari Aspergillus niger pada media basal mendapatkan suhu optimum antara $45^{\circ} \mathrm{C}$ dan $55^{\circ} \mathrm{C}$ dengan aktivitas sebesar 1,98 U/mL.

\section{Efek Penambahan Larutan Garam Mineral Mandels pada Media Fermentasi terhadap Produksi $\beta$-Glukosidase}

Kapang memerlukan makronutrien oksigen, hidrogen, karbon, nitrogen dan mikronutrien $\mathrm{P}, \mathrm{K}, \mathrm{S}, \mathrm{Mg}, \mathrm{Fe}, \mathrm{Zn}, \mathrm{Cu}$ untuk pertumbuhan
Tabel 4. Aktivitas Spesifik dan Kadar Protein Ekstrak Kasar $\boldsymbol{\beta}$-glukosidase Aspergillus niger BIO 2173 yang Diproduksi dengan Suhu Fermentasi yang Berbeda

\begin{tabular}{lcc}
\hline $\begin{array}{l}\text { Suhu } \\
\text { fermentasi } \\
\left({ }^{\circ} \mathrm{C}\right)\end{array}$ & $\begin{array}{c}\text { Kadar } \\
\text { protein } \\
(\mathrm{mg} \mathrm{m} / \mathrm{L})\end{array}$ & $\begin{array}{c}\text { Aktivitas spesifik } \\
(\mathrm{U} / \mathrm{mg} \text { protein })\end{array}$ \\
\hline 28 & $2,82 \pm 0,17$ & $1,13 \pm 0,14$ \\
32 & $2,78 \pm 0,05$ & $1,63 \pm 0,14$ \\
36 & $3,39 \pm 0,14$ & $0,95 \pm 0,09$ \\
\hline
\end{tabular}

dan aktivitas metabolitnya (Norouzian, 2008). Larutan garam mineral Mandels merupakan larutan garam yang mengandung mikronutrien $\left(\mathrm{KH}_{2} \mathrm{PO}_{4}, \mathrm{CaCl}_{2}, \mathrm{MgSO}_{4}, \mathrm{FeSO}_{4}, \mathrm{MnSO}_{4}\right.$, $\mathrm{ZnSO}_{4}, \mathrm{CoCl}_{2}$ ) dan makronutrien (urea, ammonium sulfat, pepton) (Mandels dan Reese, 1957). Penambahan larutan garam mineral Mandels ke dalam media fermentasi Aspergillus niger BIO 2173 dengan substrat dedak pada kondisi fermentasi maksimum $(\mathrm{pH} 2,0$; volume akuades $10 \mathrm{~mL}$; suhu $32^{\circ} \mathrm{C}$; waktu fermentasi 7 hari) menyebabkan peningkatan produksi $\beta$-glukosidase dengan nilai aktivitas dan aktivitas spesifik sebesar 5,24 $\pm 0,57 \mathrm{U} / \mathrm{mL}$ dan 2,46 $\pm 0,04 \mathrm{U} / \mathrm{mg}$ protein (Tabel 5).

Berdasarkan hasil penelitian Mandels dan Reese, (1957) dilaporkan bahwa mineral Ca dan $\mathrm{Mg}$ dapat mempengaruhi produksi enzim dan konsumsi glukosa. Tidak adanya $\mathrm{Mg}$ pada media fermentasi menyebabkan pertumbuhan yang lambat dan kurangnya produksi selulase. Produksi selulase meningkat dengan adanya penambahan $\mathrm{MgSO}_{4}$ dan $\mathrm{CaCl}_{2}$ pada konsentrasi hingga $0,03 \%$.

Julia et al. (2016) melakukan isolasi $\beta$-glukosidase dari Aspergillus niger NRRL3 dengan fermentasi media padat menggunakan substrat bungkil kedelai (soybean hull) dan limbah kertas dengan penambahan larutan garam mineral Mandels menghasilkan ekstrak kasar enzim dengan nilai aktivitas maksimum untuk substrat bungkil kedelai sebesar $0,984 \mathrm{U} / \mathrm{mL}$, lebih tinggi 1,7 kali daripada substrat limbah kertas. Raza et al. (2011) melakukan seleksi terhadap 10 jenis pelarut yang digunakan pada fermentasi padat produksi $\beta$-glukosidase dari campuran kultur Aspergillus niger dan A. oryzae. Hasil penelitiannya menunjukkan bahwa fermentasi dengan larutan garam mineral Mandels menghasilkan produk $\beta$-glukosidase 
Tabel 5. Aktivitas, Aktivitas Spesifik dan Kadar Protein Ekstrak Kasar $\beta$-glukosidase dari Fermentasi Aspergillus niger BIO 2173 pada Kondisi Fermentasi Maksimum (pH 2,0; Rasio Kandungan Air terhadap Substrat 1:1; Suhu Inkubasi $32^{\circ} \mathrm{C}$; Waktu Fermentasi 7 hari)

\begin{tabular}{lccc}
\hline Perlakuan fermentasi & $\begin{array}{c}\text { Aktivitas } \\
(\mathrm{U} / \mathrm{mL})\end{array}$ & $\begin{array}{c}\text { Kadar protein } \\
(\mathrm{mg} / \mathrm{mL})\end{array}$ & $\begin{array}{c}\text { Aktivitas spesifik } \\
(\mathrm{U} / \mathrm{mg} \text { protein) }\end{array}$ \\
\hline Tanpa penambahan larutan Mandels & $4,13 \pm 0,35$ & $1,75 \pm 0,05$ & $2,35 \pm 0,13$ \\
Dengan penambahan larutan Mandels & $5,24 \pm 0,57$ & $2,13 \pm 0,27$ & $2,46 \pm 0,04$ \\
\hline
\end{tabular}

yang lebih tinggi dibandingkan pelarut lainnya. Hal ini kemungkinan disebabkan karena medium yang menggunakan larutan garam Mandels mengandung semua nutrisi tambahan, sumber nitrogen baik organik (urea dan pepton) maupun anorganik (ammonium sulfat) dan konsentrasi Tween-80 yang tinggi, dimana komponenkomponen tersebut dapat meningkatkan produksi $\beta$-glukosidase (Chellapandi dan Jani, 2008).

\section{Kesimpulan}

Produksi $\beta$-glukosidase dari Aspergillus niger BIO 2173 dengan fermentasi media padat dipengaruhi oleh beberapa faktor, yaitu $\mathrm{pH}$ awal media fermentasi, waktu inkubasi fermentasi, kandungan air dalam substrat media fermentasi dan suhu inkubasi fermentasi. Produksi $\beta$-glukosidase mencapai maksimum pada $\mathrm{pH}$ awal media fermentasi 2,0, waktu inkubasi fermentasi 7 hari, perbandingan (rasio) kandungan air terhadap substrat dedak sebesar 1:1 dan suhu inkubasi fermentasi $32^{\circ} \mathrm{C}$. Penambahan larutan garam mineral Mandels ke dalam media fermentasi pada kondisi fermentasi maksimum menyebabkan peningkatan aktivitas ekstrak kasar $\beta$-glukosidase sebesar 26,88\% dibandingkan dengan fermentasi tanpa penambahan larutan garam mineral Mandels.

\section{Ucapan Terimakasih}

Ucapan terimakasih disampaikan kepada Kemenristekdikti atas bantuan dana beasiswa karyasiswa program pascasarjana tahun 2012 - 2016.

\section{Daftar Pustaka}

Ahmed, A., Nasim, F.U.H., Batool, K., Bibi, A. (2017) 'Microbial $\beta$-glucosidase: Sources, Production and Applications', Journal of Applied \& Environmental Microbiology, 5(1), pp. 31-46.
Ahmed, S.A., El-Shayeb, N.M.A., Hashem, A.G.M., Saleh, S.A.A., Abdel-Fattah, A.F. (2015) 'Chemical Modification of Aspergillus niger $\beta$-glucosidase and Its Catalytic Properties',Brazilian Journal of Microbiology, 46(1), pp. 23-28.

Bakri, Y., Jawahar,M.,Arabi,M.I.E.(2008) 'Improvement of Xylanase Production by Cochliobus sativus in Submerged Culture', Brazilian Journal of Microbiology, 39, pp. 602-604.

Carrillo-Sancen, G., Carrasco-Navarro, U., Tomasini-Campocosio, A., Corzo, G., Pedraza-Escalano, M.M., Favela-Torres, E. (2016) 'Effect of Glucose as a Carbon Repressor on The Extracellular Proteome of Aspergillus niger During The Production of Amylases by Solid State Cultivitation', Process Biochemistry, 51(12), pp. 2001-2010.

Chellapandi, P., Jani, H.M. (2008) 'Production of Endoglucanase by The Native Strains of Streptomyces Isolates in Submerged Fermentation', Brazilian Journal of Microbiology, 39(1), pp. 122-127.

Elshafei, A.M., Hassan, A.M., Morsi, N.M., Elghonamy, D.H. (2011) 'Purification and Some Kinetic Properties of $\beta$-glucosidase from Aspergillus terreus NRRL 265', African Journal of Biotechnology, 10(84), pp. 19556-19569.

Gao, Z., Hop, D.V., Yen, L.T.H., Ando, K., Hiyamuta, S., Kondo, R. (2012) 'The Production of $\beta$-glucosidase by Fusarium proliferatum NBRC109045 Isolated from Vietnamese Forest', $A M B$ Express, 2(1)(49), pp. 1-13.

Gautam, S.P., Bundela, P.S., Pandey, A.K., Khan, J., Awasthi, M.K., S. Sarsaiya, S. (2011) 'Optimization for The Production of Cellulase Enzyme from Municipal Solid Waste Residue by Two Novel Cellulolytic Fungi' Biotechnology Research International, 2011, pp. 1-8.

Herr, D., Baumer, F., Dellweg, H. (1978)'Purification and Properties of an Extracellular $\beta$-glucosidase from Lenzites trabea',European Journal of Applied Microbiology and Biotechnology, 5(1), pp. 29-36. 
Hu, H.L., van den Brink, J.K, Gruben, B.S., Wösten, H.A.B., Gu, J.D., de Vries, R.P.(2011) 'Improved Enzyme Production by Co-Cultivation of Aspergillus niger and Aspergillus oryzae and with Other Fungi', International Biodeterioration \& Biodegradation, 65, pp. 248-252.

Ikram-ul-Haq,Javed, M.M., Khan, T.S. (2006) 'An Innovative for Hyperproduction of Cellulolytic and Hemicellulolytic Enzymes by Consortium of Aspergillus niger MSK1 and Trichoderma viride MSK-10', AfricanJournal of Biotechnology,5(8), pp. 609-614.

Irshad, M., Anwar, Z., Ramzan, M., Mahmood, Z., Nawaz, H. (2013) 'Characterization of Purified $\beta$-glucosidase Produced from Trichoderma virideThrough Bio-processing of Orange Peel Waste', Advances in Bioscience and Biotechnology, 4, pp. 941944.

Joo, A.R., Jeya, M., Lee, K.M., Lee, K.M., Moon, H.J., Kim, Y.S., Lee, J.K. (2010) 'Production and Characterization of $\beta-1,4-G l u c o s i d a s e$ from a Strain of Penicillium pinophilum', Process Biochemistry, 45, pp. 851-858.

Julia, B.M., Belen, A.M., Georgina, B., Beatriz, F. (2016) 'Potential Use of Soybean Hulls and Waste Paper as Supports in SSF for Cellulase Production by Aspergillus niger', Biocatalyst and Agricultural Bitechnology, 6, pp. 1-8.

Junior, A. B.,Borges, D.G., Tardioli, P.W., Farinas, C.S.(2014) 'Characterization of $\beta$-glucosidase Produced by Aspergillus nigerUsing Solid-State Fermentation and Partially Purified Using MANAE-Agarose' Biotechnology Research International, (2014), pp. 1-8.

Krisch, J., Takó, M., Papp, T., Vágvölgyi, C. (2010) 'Characteristics and Potential Use of $\beta$-Glucosidase from Zygomycetes', Current Research, Technology Education Topics in Applied Microbiology and Microbial Biotechnologogy. A. Mendez-Vilaz (Ed.), pp. 891-896.

Liu, D., Zhang, R., Yang, X., Zhang, Z., Song, S., Miao, Y., Shen, Q. (2012) "Characterization of a Thermostable $\beta$-glucosidase from Aspergillus fumigatus Z5, and Its Functional Expression in Pichia pastoris X33', Microbial Cell Factories, 11(25), pp. 1-15.

Lonsane, B.K., Ghildyal, N.P., Budiatman, S., Ramakhrisna, S.V. (1985) 'Engineering Aspects of Solid State Fermentation'. Enzyme and Microbial Technology, 7(6), pp. 258-265.
Lowry, O.H., Rosebrough, N.J., Farr, A.L., Randall, R.J. (1951) 'Protein Measurement with The Folin Phenol Reagent', Journal of Biological Chemistry, 193, pp. 265-275.

Mandels, M., Reese, E.T. (1957) 'Induction of Cellulase in Trichoderma viride as Influenced by Carbon Sources and Metals', Journal of Bacteriology', 73, pp. 269-278.

Norouzian, D. (2008) 'Effect of Different Factors on Fermentative Production of Enzymes by Fungi. Dynamic Biochemistry', Process Biotechnology and Molecular Biology, 2(1), pp. 14-18.

Park, A.H, Hong, J.H., Kim, J.J., Yoon, J.J. (2012)'Biochemical Characterization of an Extracellular $\beta$-glucosidase from the Fungus, Penicillium italicum, Isolated from Rotten citrus peel', Mycrobiology, 40(3), pp. 173-180.

Qian, L.C.,Fu, S.J., Zhou, H.M., Sun, J.Y., Weng, X.Y.(2012) 'Optimization of Fermentation Parameters for $\beta$-glucosidase Production by Aspergillus niger', Journal of Animal and Veterinary Advances, 11(5), pp. 583-591.

Rajoka, M.I., Khan, S., Latif, F., Shahid, R. (2004) 'Influence of Carbon and Nitrogen Sources and Temperature on Hyperproduction of a Thermotolerant $\beta$-glucosidase from Synthetic Medium by Kluyveromyces marxianus', Appl. Biochem. Biotechnol., 117(2), pp. 75-92.

Raza, F., Raza, N.A.,Hameed, U., Ikram-ul-Haq, Mariam, I. (2011) 'Solid State Fermentation for the Production of $\beta$-glucosidase by CoCulture of Aspergillus niger and A. oryzae', Park. J. Bot., 43(1), pp. 75-83.

Salihu, A., Bala, M., Alam, Md.Z. (2016) 'Lipase Production by Aspergillus niger Using Sheanut Cake: An Optimization Study', Journal oF Taibah University of Science, 10, pp. 850-859.

Silva, D.M., Batista, L.R., Rezende, E.F., Fungaro, M.H.P, Sartori, D., Alves, E. (2011) 'Identification of Fungi of The Genus Aspergillus Section Nigri Using Polyphasic Taxonomy' Brazilian Journal of Microbiology, 42, pp. 761-773.

Singhania, R.R., Patel, A.K., Sukumaran, R.K., Larroche, C., Pandey, A. (2013) 'Role of Significance of Beta-Glucosidases in The Hydrolysis of Cellulose for Bioethenol Production', Bioresource Technology, 127, pp. 500-507.

Yang, L., Lubeck, M., Lubeck, P.S. (2017) 'Aspergillus as a Versatile Cell Factory for Organic Acid Production', Fungal Biology Reviews, 31(1), pp. 33-49. 
Zahoor, S., Javed, M.M., Aftab, S., Latif, F.,ulHaq, I.,(2011) 'Metabolic Engineering and Thermodynamic Characterization of an Extracellular $\beta$-glucosidase Produced by Aspergillus niger',African Journal of Biotechnology, 10(41), pp. 8107-8116.
Zheng, W., Chen, X., Xue, Y., Hu, J., Gao, M.T., Tsang, Y.F. (2017) 'The Influence of Soluble Polysaccharides Derived from Rice Straw upon Cellulose Production by Trichoderma reesei', Process Biochemistry, 61, pp. 130136. 